\title{
Studies of Utilization of Rural Health Post Based on Knowledge and Community Attitude
}

\author{
Zuhrina Aidha ${ }^{1}$, Reni Agustina Harahap ${ }^{2}$ \\ ${ }^{1,2}$ Lecture in Public Health Faculty Islamic State University of Sumatera Utara, Indonesia \\ zuhrina87@yahoo.com \\ reniharahap.agustina77@gmail.com
}

\begin{abstract}
Poskesdes (Rural Health Post) is a Community-Based Health Effort established to optimalize the potentials existing in the community to improve the health status and the utilization of health services. This quantitative study was to analyze utilization of rural health post by the knowledge and attitude in Kutalimbaru Subdistrict, Deli Serdang District. The data for this study were obtained through questionnaire-based interview with 80 respondents comprising the mothers with babies/children under five years old.

The result of this study showed that $50 \%$ of the respondents were of 20-30 years old and $28.8 \%$ had negative relationship with the utilization $(-\mathbf{0 . 2 8 8})$. The majority of the respondents $(48.7 \%)$ were SMA (High School) graduates and $18.6 \%$ had relationship with the utilization $(0.186)$. The knowledge of the respondents $(85 \%)$ about Poskesdes was good and $22.2 \%$ had relationship with the utilization $(0.222)$. The attitude of the respondents $(67.5 \%)$ towards Poskesdes was good and $49.4 \%$ had relationship with the utilization (0.494). Knowledge was the dominant influence on the utilization rural health post $(\mathrm{p}=\mathbf{0 , 0 2 7}<0,05)$.

It is suggested to improve the role of community members in health activities and the provision of information that the community members would prefer visiting the Poskesdes to have their health checked, to provide more extension and to hold more meetings with the community members that the community members are willing to optimalize the utilization of Poskesdes.
\end{abstract}

Keywords - Knowledge, attitude, Poskesdes, utilization, utilization rural health post

\section{INTRODUCTION}

The establishment of Community Based Health Effort (UKBM) aims to help the public in using health services. UKBM formed on the basis of the needs of the community, managed by from, for and with the community, with the guidance of a health worker, cross-sector and other relevant institutions. Posyandu is one of UKBM that provide convenience to the public in obtaining basic health services to accelerating the reduction of maternal mortality and infant [1]. Efforts to further strengthen the implementation of various UKBM in the village, need to develop a form of UKBM to coordinate all existing UKBM. This coordination function is required so that the implementation can be synergistic UKBM in efforts to achieve standby village. Embodiment Alert Village is to accelerate the achievement of a healthy village. UKBM the coordinative function in village it is a rural health post (Poskesdes) in accordance with Kepmenkes 564 TH.2006 on guidelines for implementation of Rural Development standby.

Poskesdes managed by a midwife and a minimum of one cadre. Activities undertaken in Poskesdes include promotive, preventive and curative include epidemiologist simple observation of the disease, especially infectious diseases and potentially extraordinary events (KLB), nutritional status, and maternal health; disease prevention; preparedness and disaster management and health emergencies; and basic medical services, according to competence.

Poskesdes visit coverage in Sub Kutalimbaru fairly high. Based Health Center report Kutalimbaru there are more than $60 \%$ of people use Poskesdes as health care first. However, a decline in some aspects. Based on data from the Health Service Deli Serdang viewable data on infants of low birth weight (LBW) in 2012 there were 2 cases $(0.26 \%)$, and this has increased compared to the year 2011 which is not a case of LBW (0\%). Infant and toddler deaths that occurred during the year 2012 as many as 1 cases has increased compared to the year 2011 which is not a case of infant and child mortality.

\section{PROBLEMS}

The increasing incidence of low birth weight and infant mortality in Sub Kutalimbaru be interesting to study the problems. This increase is due there are still people who do not take advantage of Poskesdes. Under these conditions, the formulation of the research problem is what are the determinants of 
utilization poskesdes on families in Deli Serdang district Kutalimbaru subdistrict 2014.

\section{RESEARCH OBJECTIVES}

This study aims to analyze the utilization Poskesdes in terms of knowledge and attitudes of people in the District of Deli Serdang regency Kutalimbaru 2014.

\section{BENEFITS RESEARCH}

1. Health Center, as consideration in finding problems associated with fewer visits to Poskesdes society.

2. Communities. The result is expected to be a medium to improve public knowledge about Poskesdes and other health services that can be found in the village where they live, as a spur to increase community participation in improving the health and well being independently.

3. Further research. The results of this study can be used as a reference to carry out further research related to factors that support the harness poskesdes society.

\section{METHODS}

This study uses a quantitative research to analyze the utilization Poskesdes based on Kutalimbaru families in Deli Serdang. The population in this study is a family in the district Kutalimbaru totaling 9143 households. The total sample of 80 mothers who have children and take advantage of Poskesdes within six months.

Methods of data analysis used in this research is descriptive analysis.

The population in this study is a family in the district of Deli Serdang Kutalimbaru 2014. Based on data from the initial survey is known that in 2013 the number of families in the District of Deli Serdang Kutalimbaru amounted to 9143 households. Samples numbered 80 people taken by simple random sampling method. Samples are family (mother) that utilizes poskesdes Kutalimbaru in the last six months.

\section{RESULTS AND DISCUSSION}

Characteristics of respondents were seen in the study just as supportive data but not to be studied, including age and education. Based on the research that the majority of respondents aged 20-30 years as many as 40 respondents $(50 \%)$. The majority of respondents have an education past high school level as much as 39 respondents $(48.7 \%)$.

Poskesdes between age and utilization, of the 80 respondents consisting of 40 respondents aged 20-30 years, and which utilizes Poskesdes 31 people (38.8\%) and were not as many as 9 people $(22.5 \%)$. Respondents aged 31-40 years as many as 24 people who utilize Poskesdes as many as 4 people $(16.7 \%)$ and that do not take advantage of as many as 20 people $(83.3 \%)$. And respondents aged 41-50 years as many as 16 people who take advantage of as much Poskesdes $2(12.5 \%)$ and did not take advantage of as many as 14 people $(87.5 \%)$.

Between education and the use of Poskesdes obtained 13 respondents with elementary education, as many as five people (38.5\%) who use and 8 $(61.5 \%)$ did not take advantage. Of the 20 respondents junior high school $9(45 \%)$ utilize Poskesdes and $11(55 \%)$ did not take advantage. Then out of 39 respondents had high school 20 people $(51.3 \%)$ utilize and 19 people $(48.7 \%)$ did not take advantage. A total of 5-educated respondents Academy, 3 (60\%) take advantage of, and $2(40 \%)$ did not take advantage. Respondents educated to degree as many as three people, one person (33.3\%) utilize and $2(66.7 \%)$ did not take advantage.

Results of cross tabulation between age and utilization, as many as 31 people $(77.5 \%)$ who use Poskesdes. The higher the age, the lower the utilization Poskesdes. In this study, respondents with the largest age is the age of 20-30 years (30 people). The older the person the more the function of organs impaired impact on the limited space for someone to take advantage of health services [2].

Siregar 2012 in his study mentions no significant relationship between age and utilization of antenatal care [3]. The results of this study showed that the older a person tends not utilize Poskesdes. This is because the service Poskesdes incomplete and capable of handling serious illnesses and disease perceived the elderly, so they choose a better health service.

Low Poskesdes visit the elderly respondents caused by Poskesdes services. Until now Poskesdes optimally serve maternal and child health $(\mathrm{MCH})$ for Poskesdes in Deli Serdang is a change from 
Polindes, which only serve antenatal, delivery, postpartum care, immunization and family planning. At an advanced age, needed better health care and in complete accordance with the complaints of disease in the suffering and not able to be handled in Poskesdes. Therefore, respondents with advanced age does not utilize Poskesdes.

Usually the higher the level of education increases one's cause is also the science and knowledge, resulting in increased needs and demands for health services better (Hardiwinoto, 2007).

A significant relationship between education and utilization IHC / Polindes [4]. This is because the lower the mother's education lead to poor knowledge of the GMP services / Polindes which resulted in low utilization of IHC / Polindes. low maternal education will result in low knowledge of maternal influence on a mother's decision to get health care [4].

Newman and Andersen (1975) in Siregar (2012) states that a person's education is indirectly affecting the utilization of health services. Education is the basis for variations in knowledge, attitudes and values towards a health service [3]. Furthermore, these variations have an impact on health care utilization variation. Education will encourage individuals and is one of the important elements that can affect the state of a person with a higher level of education are expected knowledge or information about the utilization of health services will be better.

Between knowledge and utilization of acquired Poskesdes 68 people with good knowledge, 35 people $(51.5 \%)$ utilize Poskesdes and $33(48.5 \%)$ did not take advantage of Poskesdes. Then from 12 respondents with low knowledge, $2(16.7 \%)$ utilize and 10 people $(83.3 \%)$ did not take advantage.

A person's behavior in the utilization of health services motivated by three factors, one of them is a predisposing factor that includes about knowledge [6]. In this study, the overall rate of mothers who have a good knowledge of the average utilizing Poskesdes, but there are some respondents who have a good level of knowledge but its utilization is less.

The results are consistent with the theory put forward Andersen (1995) in Siregar (2012) which revealed that the utilization of health services has three factors at play, namely predisposing factors, enabling factors, and factors needs [3]. Utilization of service health dependent on sociodemographic factors, level of education, beliefs and cultural practices, gender discrimination, the status of women, environmental, political and economic system, pattern of disease and the health care system.

Health knowledge will affect the person's behavior as a medium-term results of education obtained. Health behaviors will affect the increasing public health indicators as a result of health education. Ignorance of mothers and families of the importance of prenatal care of pregnant women did not have an impact on checkups at health care workers [1].

Endah research results (2008) states that there is a positive relationship between knowledge and completeness of basic immunization. The same conclusion from a survey in India by Nepal Demographic Health Survey (Vaessen, 2002) quoted Ginting (2008) in 2001 showed that many mothers have knowledge of current pain treatment measures more health facilities [7].

Between attitude to the use Poskesdes acquired 54 people with a good attitude, 37 (68.5\%) utilize Poskesdes, whereas $17(31.5 \%)$ did not take advantage. Then from 26 people with less attitude, as many as 26 people (100\%) are not utilizing.

The attitude factor of greatest health care (dominant) influence utilization Swadana Tarutung RSU [8].

Based on the theory stated [6], attitude is a reaction or response which was still closed from a person to a stimulus or object. Manifestations attitude can not be seen directly, but can only be interpreted in advance of behaviors covered, and attitudes are usually based on knowledge. The attitude of society which lacks a Poskesdes service utilization can also be attributed to lack of knowledge and low level of education possessed by the mother in the District Kutalimbaru.

The results are consistent with research Pamungkas 2009 regarding attitudes about posyandu as factors that affect the utilization of Posyandu is consistent with research that of the respondents who have a good attitude towards posyandu have the opportunity to visit 4-5 times posyandu compared with respondents who had levels less attitude, In the results that have been obtained frequency relationship most is the level of respondents' attitudes are less and less quantity of visits to neighborhood health center [9]. Lack attitude of 
mothers to posyandu caused by a lack of motivation of respondents follow a series of activities posyandu classically due to excessive levels of activity.

The study also Sejala with Arwiani research 2013 shows that the attitude towards antenatal care facilities affect the utilization of antenatal care at the health center [10]. Good attitude associated with satisfaction based on quality of service which refers to the degree of perfection of the appearance of health services in accordance with the level of resident satisfaction. In providing services to customers, providers and service providers should endeavor to refer to the main purpose of this service and customer satisfaction pencapaiaan where customer satisfaction is a response to the unmet needs and expectations (Anwar, 1997).

Multivariate analysis obtained knowledge factors as the most significant factors related to the utilization Poskesdes with a significance value of 0.027 .

The results of this study are consistent with the opinion of Kalangie (1994) which states that the knowledge and resources of the health service as a factor that consumers can influence the utilization of health services. The factors that influence the utilization of health services from the consumer factor [11].

\section{CONCLUSION}

A total of 68 respondents good knowledge, which utilizes Poskesdes only 35 people. 33 people who either do not utilize Poskesdes knowledgeable.

A total of 54 people with a good attitude, as many as 37 people are utilizing Poskesdes. While 17 people do not take advantage of poskesdes.

Between knowledge and attitudes towards Poskesdes, which most affect the utilization Poskesdes is knowledge.

\section{REFERENCES}

[1] Keputusan Menteri Kesehatan RI 564/Menkes/SK/VII1/2006 tentang Pelaksanaan Pengembangan Desa Siaga. Jakarta.

[2] Henniwati. 2008. Faktor-faktor yang Mempengaruhi Pemanfaatan PEayanan Posyandu Lansia di Wilayah Kerja Puskesmas Kabupaten Aceh Timur 2008. http://repository.usu.ac.id/. Diakses pada 23/2/2014.

[3] Siregar, Nuraijah. 2012. The factors that Affect the utilization of ANC Services in the region of clinics Sosopan Padang Lawas Regency in 2012. Terrain: USU.

[4] Sugiharti and Heny. 2011. The factors that Affect the utilization of Posyandu/Polindes on pregnant women in Indonesia. http://ejournal.litbang.depkes.go.id
[5] Ristrini dan Budiarto W. 2005. Utilisasi Pelayanan Kesehatan Maternal oleh Masyarakat Miskin di Pedesaan dalam Rangka Kehamilan Aman, BKM/XX1/01/Maret 2005. http://i-lib.ugm.ac.id/jurnal/download/php.

[6] Notoatmodjo, Soekidjo. 2005. Pendidikan dan Perilaku Kesehatan. Jakarta: Rineka Cipta.

[7] Ginting, Idau. 2001. Faktor-faktor yang Berhubungan dengan Pamanfaatan Palayanan Antenatal oleh Ibu Hamil yang Memiliki Faktor Risiko di Kecamatan Pesanggrahan Jakarta Selatan Tahun 2001. Tesis. Program Pascasarjana Fakultas Kesehatan Masyarakat Universitas Indonesia.

[8] Matondang, ESS. 2012. Pengaruh Kepercayaan masyarakat terhadap pemanfaatan RSU Swadana Tarutung tahun 2011. http://repository.usu.ac.id/bitstream/ 123456789/3/chapter20III-VIpdf. Diakses pada 25 Mei 2014.

[9] Pamungkas, L. 2009. Hubungan antara Faktor Pengetahuan, Sikap dan Kepercayaan dengan Perilaku Ibu Berkunjung Ke Posyandu di Kelurahan Grabag Kecamatan Grabag Kabupaten Magelang. Program Pascasarjana Universitas Diponegoro Semarang.

[10] Arwiani, Tuni. 2013. Faktor-faktor yang Mempengaruhi Pemanfaatan Pelayanan Antenatal di Puskesmas Kota Bandung Tahun 2013. http://pustaka.unpad.ac.id/wp-content/

[11] Madunde, Kristian J; Frans. J Pelealu; Paul Kawatu. 2013. Faktor-faktor yang Berhubungan dengan Pemanfaatan Pelayanan Kesehatan di Puskesmas Kema Kecamatan Kema Kabupaten Minahasa Utara. http://fkm.unsrat.ac.id/wp-content/uploads/2013/08/KRISITIAN-J-

MADUNDE-091511085.pdf. diakses pada tanggal 16 April 2014. 